\title{
Role of Ecosystem Development and Climate Change in Bog Formation in Central Sweden
}

\section{Citation}

Foster, D. R., and H. E. Wright. 1990. Role of Ecosystem Development and Climate Change in Bog Formation in Central Sweden. Ecology 71, no. 2: 450-463. Portico. doi:10.2307/1940300.

\section{Published Version}

doi: $10.2307 / 1940300$

\section{Permanent link}

http://nrs.harvard.edu/urn-3:HUL.InstRepos:30675716

\section{Terms of Use}

This article was downloaded from Harvard University's DASH repository, and is made available under the terms and conditions applicable to Other Posted Material, as set forth at http:// nrs.harvard.edu/urn-3:HUL.InstRepos:dash.current.terms-of-use\#LAA

\section{Share Your Story}

The Harvard community has made this article openly available.

Please share how this access benefits you. Submit a story.

\section{Accessibility}




\title{
ROLE OF ECOSYSTEM DEVELOPMENT AND CLIMATE CHANGE IN BOG FORMATION IN CENTRAL SWEDEN ${ }^{1}$
}

\author{
D. R. FOSTER \\ Harvard Forest, Harvard University, Petersham, Massachusetts 01366 USA \\ H. E. WRIGHT, JR. \\ Limnological Research Center, 218 Pillsbury Hall, \\ University of Minnesota, Minneapolis, Minnesota 55455 USA
}

\begin{abstract}
Bog development, in terms of the rates of horizontal and vertical accumulation of peat and the timing of landform development of open-water pools, was examined on two concentric raised bogs in central Sweden. The results are compared with three models (allogenic, autogenic, and neutral models) of bog development in order to evaluate the relative contribution of environmental factors vs. ecosystem control of developmental processes. Both mires began to grow on discrete upland sites $\approx 6000 \mathrm{BP}$ and then spread concentrically and accumulated peat vertically at approximately continuous rates to the present. Radiocarbon dates from pool sediments are progressively younger from the center to the margin of the mire, suggesting that pool formation is triggered autogenically by changes in hydrology. The results conform to hydrological models of mire formation based on groundwater mound equations and suggest that autogenic processes exert a major control over bog expansion, landform development, and the formation of conspicuous features in the stratigraphic record.
\end{abstract}

Key words: autogenic; bog; climate; mire; paleoecology; Sweden.

\section{INTRODUCTION}

The paleoecological reconstruction of past environments has relied historically on macrofossil, microfossil, and lithological information derived from peat and lake sediments. Mires were the focus of many early studies in part because of the relative ease of obtaining stratigraphic samples from open exposures in the peat cuttings that occur throughout central and northwestern Europe (Godwin 1981). Mires continue to be used for vegetational and climatic reconstructions because they offer particular advantages over lake sites, notably: (1) raised bogs, which receive their moisture and nutrients primarily from atmospheric inputs, may be more sensitive to environmental fluctuations than sites in the surrounding upland (Barber 1981, Aaby 1986, Moore 1986), (2) the abundance of macrofossils and their generally good state of preservation in peat provide direct information on the vegetation at the sampling location (Tolonen 1971, Janssens 1983, Dupont 1986), and (3) peatlands collect local microfossil records that document small-scale vegetation patterns across the mire and adjacent areas (van Geel 1978, Jacobson and Bradshaw 1981, Tolonen et al. 1985).

As a result of these distinctive characteristics, mirebased studies have been and continue to be of major importance in the field of paleoecology (von Post and Sernander 1910, Granlund 1932, Nilsson 1983, Aaby 1986). However, much of the rationale for interpreting

\footnotetext{
${ }^{1}$ Manuscript received 9 January 1989; revised 24 May 1989; accepted 26 May 1989.
}

peat stratigraphy was formulated before the development of the theoretical understanding necessary to evaluate it thoroughly (Birks and Birks 1980, Godwin 1981). The consequence has been a continual reevaluation of many basic assumptions and a concomitant increase in the understanding of bog dynamics and its complex interrelationship with environment (Casparie 1969, Damman 1979, Clymo 1984).

A particular case is the use of recurrence surfaces for stratigraphic correlation, dating, and environmental reconstruction. The idea was introduced by Blytt (1876), and subsequently expanded by Granlund (1932); recurrence surfaces are layers of fresh, well-preserved peat overlying a discrete layer of humified peat and were interpreted as synchronous surfaces caused by a change from dry conditions (humified peat) to moist, cool conditions (well-preserved peat). Five or more of these layers were identified on classic Swedish sites (Granlund 1932), and these in turn were used for correlation across a bog (Granlund 1932), a landscape (Lundqvist 1958), and broad regions (Godwin 1946, Berglund et al. 1984). Aspects of the recurrence-surface concept were criticized rather early, on the basis of an intuitive understanding of bog growth and climate change (Früh and Schröter 1904, von Post 1925, Conway 1948). Only with the availability of radiocarbon dating and improved appreciation of bog hydrology has it been shown that the classic recurrence surfaces were often asynchronous (G. Lundqvist 1963, J. Lundqvist 1969), that the fundamental model of bog development and environmental response underlying 
this interpretation was incomplete (Ingram 1983, Clymo 1984), and that interpretation of the stratigraphic record required consideration of complex interrelationships and inherent delays in system response (Casparie 1969, Frenzel 1983, Tolonen et al. 1985).

In the present study we examine two other stratigraphic characteristics of northern peatlands that have been widely used for reconstructing regional environmental conditions. These are: (1) the use of basal radiocarbon dates as indications of peatland inception and inferred climate change, and (2) the use of pool sediments or other indicators of surface pattern (hummock/hollow, hummock/pool) development as proxies for changes in regional moisture balance. Our objective is to determine the relative role that allogenic environmental factors and autogenic developmental processes play in bog development and in controlling the formation of surface landforms. Resolution of these issues should help future paleoenvironmental reconstructions while addressing fundamental questions of ecosystem development and function.

We first explore relevant models of mire development and pattern formation as controlled by allogenic and autogenic processes and outline expected stratigraphic patterns based on each model. The fieldwork and results are then described, followed by a discussion of their significance in terms of the proposed models and their implication for the understanding of ecosystem development. The field sites in this study are Hammarmossen (Figs. 1 and 2) and Nittenmossen (Fig. 3), raised bogs in central Sweden that contain well-developed hummock, hollow, and pool microtopography (Granlund 1932, Sjörs 1948, Foster et al. 1988).

\section{Raised bog ecosystems}

Raised bogs are wetland ecosystems characterized by a convex cross section and a broad distribution in cool temperate areas especially in the Northern Hemisphere (Gore 1983). As a consequence of their domed shape bogs are ombrotrophic, i.e., their surface is isolated from groundwater, and nutrients and moisture are derived from atmospheric sources. In the resulting acid and nutrient-poor environment decomposition rates are slow and organic material accumulates to a peat depth generally ranging from 1 to $10 \mathrm{~m}$, making raised bog systems the single greatest sink for organic material among wetland types, worldwide (Ingram 1983). The surface of raised bogs is covered predominantly by Sphagnum, sedges, and ericaceous plants that form a microtopographic pattern of firm elevated hummocks or ridges and low, moist hollows. Especially in northern and maritime regions the microtopography is accentuated into robust and broad ridges and deep hollows and open-water pools. Such mires are widespread and form prominent parts of the landscape in Canada, Scandinavia, European Russia, and central Siberia (Ivanov 1981, Sjörs 1983, Foster and Glaser 1986).

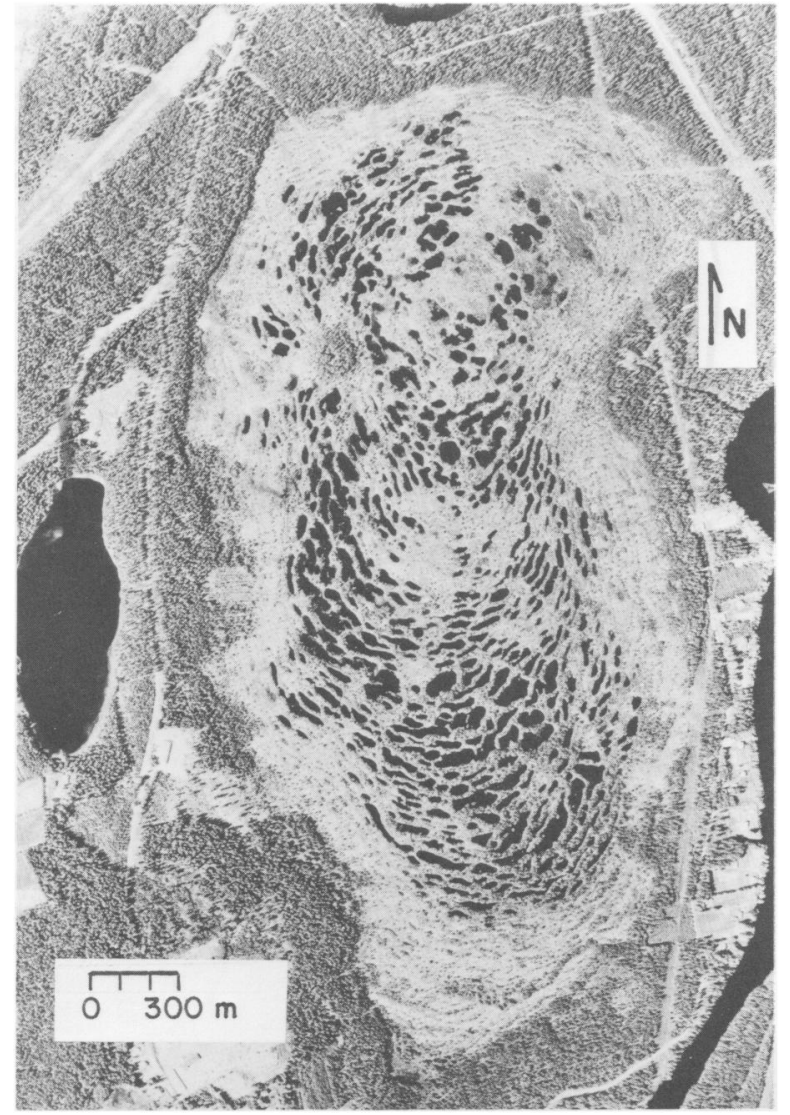

Fig. 1. Aerial photograph of Hammarmossen showing the well-developed pool systems, which give way towards the bog margin to a concentric hummock-hollow pattern and upland forest of Pinus sylvestris.

\section{Bog and bog-pool development: environmental interpretations and empirical models}

Three distinct models of raised bog development on upland sites may be outlined (Fig. 4): (A) peat initiation across a broad area followed by gradual vertical increase in height but no lateral expansion, (B) peat initiation at numerous loci followed by expansion and fusion of the separate mires into a single mire complex, and (C) peat initiation at a central locus followed by gradual increase in height and horizontal extent. Each model predicts very different results for a series of basal peat dates. For example, only for model (A) would the basal date in several cores be always the same. The other models would give a series of different dates. Thus these models should be easily differentiated through the study of a series of basal radiocarbon dates.

At least three distinct models for pool formation can be distinguished (Fig. 5), including: (A) allogenic, climatic model, (B) autogenic, ecosystem model, and (C) neutral model which states that pools have always existed on the mire. For each model contrasting predictions emerge concerning pools and their (i) age distribution, (ii) spatial distribution, and (iii) morphometry. 

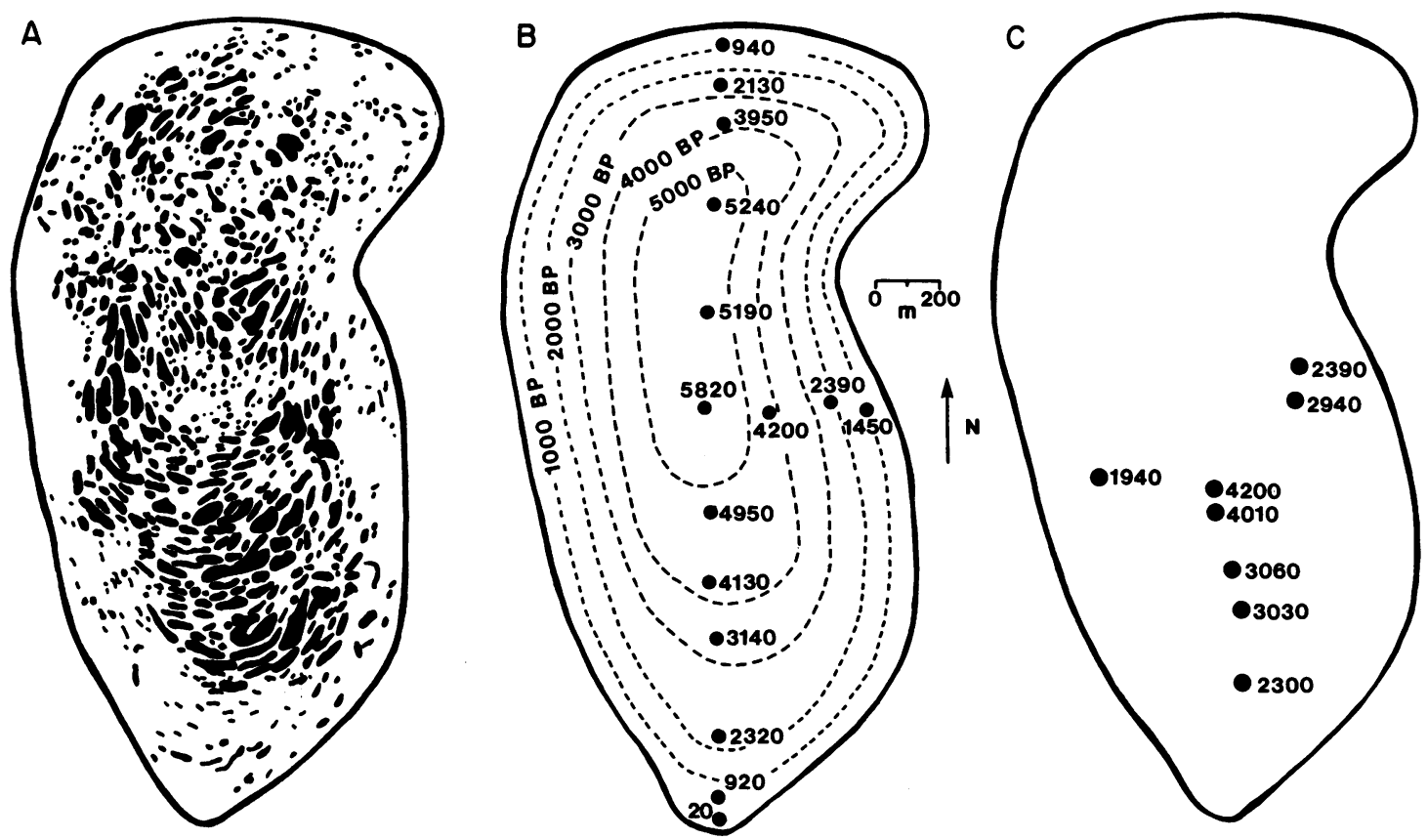

FIG. 2. Map of Hammarmossen showing: (A) the distribution and size of the open-water pools (dark), (B) the location and age of basal radiocarbon dates and interpolated isochrones for bog expansion (cf. Foster et al. 1988), and (C) the location and ages of pools studied in the current study.

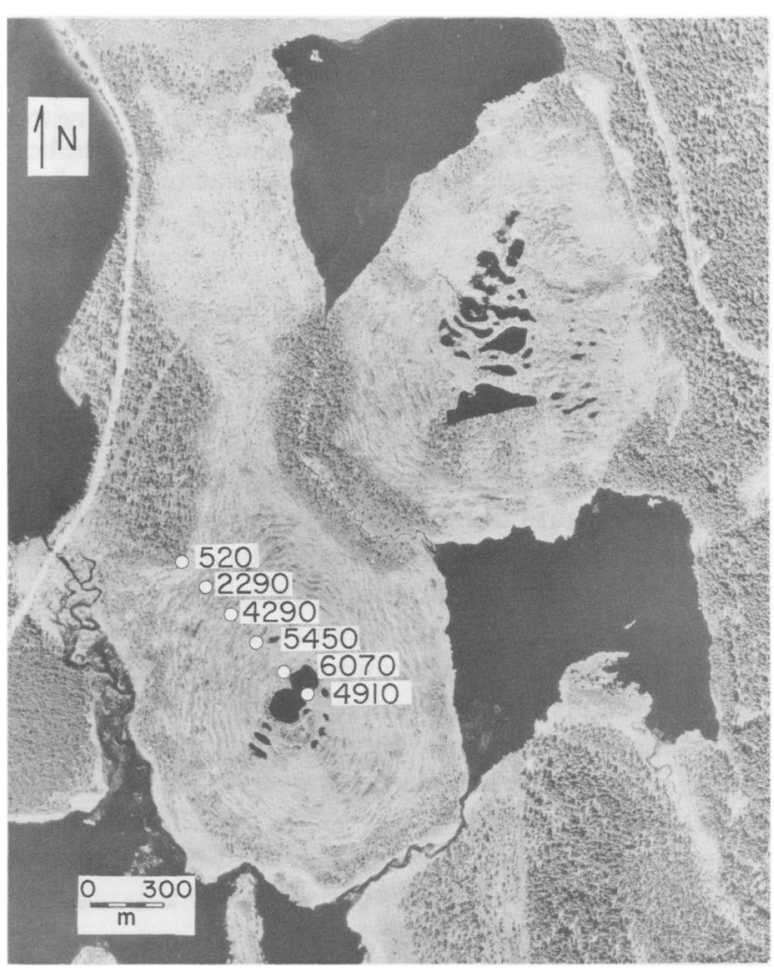

Fig. 3. Aerial photograph of Nittenmossen, showing the large central pool formed by the fusion of adjacent pools and the concentric patterns of hummock ridges (dark) and hollows (light). The location of basal peat samples is indicated by the open dots and corresponding basal radiocarbon dates are shown to the right.
In the first model (allogenic model; Fig. 5A) pools form simultaneously across a bog in response to broad-scale climatic change. Pools therefore should be similar in age and depth. In model two (autogenic model; Fig. 5B) pool formation is triggered by autonomous processes as portions of the mire pass through a critical stage of development, which might be controlled, e.g., by bog morphology (Grossformen sensu Aario 1932), peat depth, or hydrology. Pool formation would be time dependent and centripetal, and pool ages and depth might be correlated positively with basal peat age and depth. In the third model (neutral model; Fig. 5C) pools form simultaneously with peat initiation. Pool age and depth would be equivalent to that of the adjacent peat.

The classic interpretation of pools as hydroclimatic features that respond closely to regional climatic variation (allogenic model) is best summarized in the studies by Barber (1981) on Bolton Fell Moss. In this view the relative area of hummock vs. pool on the mire surface is directly controlled by climate (moisture surplus). During dry periods hummocks build and expand. A change to moister conditions causes pool formation and expansion and a general decline in the height and size of hummocks (cf. also Godwin 1954, Ruuhijärvi 1960, Walker 1961, Aartolahti 1967, Sakaguchi 1979). Pool sediments are interpreted as contemporaneous products of regional climate change and therefore are thought to be traceable across broad areas as temporal stratigraphic markers.

In the autogenic model it is envisioned that the regional climate may be suitable for the development of 

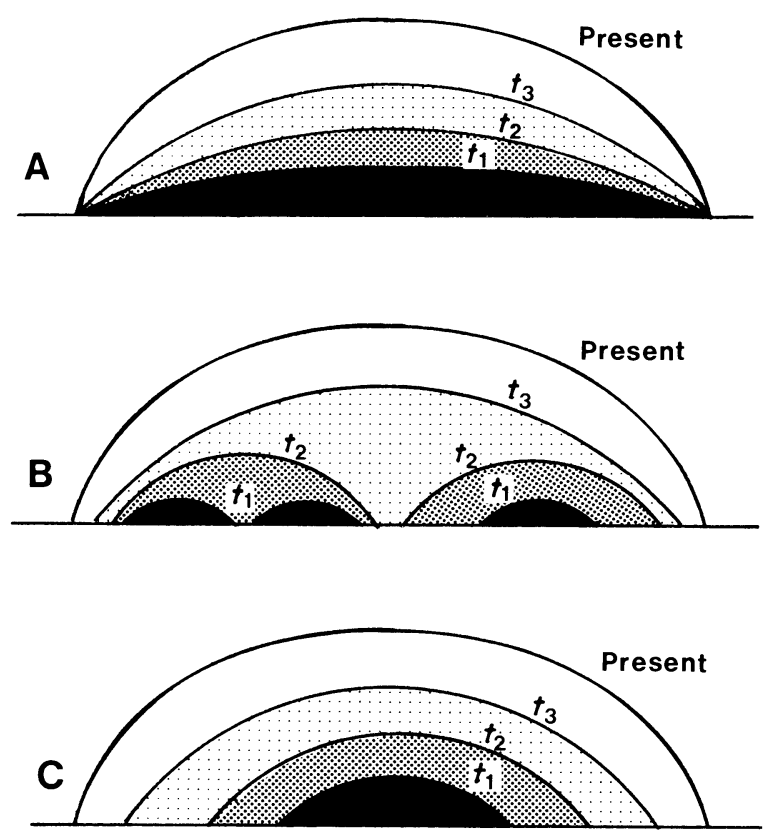

FIG. 4. Three conceptual models for the development of a concentric raised bog showing the bog at various times $\left(t_{x}\right)$ leading to the present. In (A) the mire increases in peat thickness but not horizontal extent through time, in (B) separate peatlands fuse through lateral expansion and vertical accumulation, and in (C) a single locus for peatland initiation increases in depth and extent through time.

pool patterns on mires, but that the specific timing of their formation is dependent on the bog passing through some critical threshold. The threshold might be, for example, a minimum peat depth, surface slope, or water table depth. As portions of a mire pass the (presumably hydrological) threshold, pools will form (Fig. 5B).

The third model (neutral model; Fig. 5C) is based on the interpretation of Swedish researchers that in some situations pools date from the initiation of mire formation (Osvald 1923, Granlund 1932, Lundqvist 1951). In this model pools start directly on or very close to the mineral soil as wet depressions and are permanent features on the mire. Pools therefore extend from the peat surface down to the mineral soil (cf. Granlund 1932).

The models outlined above cover the basic interpretations of landform development on mire systems, with the exception of purely physical mechanisms such as mass movement or freeze-thaw action (cf. Drury 1956, Pearsall 1956, Schenk 1966, Lindsay et al. 1985). Additional complexities could be added, e.g., changes in pool size and number in response to a fluctuating climate. However, the evidence from most sites in northern Europe and North America is that once large pools are initiated they persist through time, and therefore this simple template is used (Boatman 1983, Kuznetsov 1986, Foster and Fritz 1987).

We turn now to the relevant evidence in two Swedish raised bogs.

\section{Site Description}

Hammarmossen and Nittenmossen are located in the southern portion of the Bergslagen region of central Sweden. Across this landscape large raised bogs are characterized by the extensive development of a surface pattern of broad hummocks and pools (Sjörs 1948; Fig. 1). Hammarmossen is well described within a regional context for its gross morphology and stratigraphy (Granlund 1932) and the flora, water chemistry, and vegetation of both mires have been discussed by Sjörs (1948). Hammarmossen is situated on a broad outwash plain of fine-to-medium sand that slopes very gently to the south. Nittenmossen has formed on a level sand plain that is bordered by shallow lakes on two sides. The surface pattern of hummocks and pools on these mires forms a concentric pattern that parallels the surface topography of the bog dome.

\section{Methods}

Field work at Hammarmossen during the summers of 1986-1987 consisted of surveying the bog topography and pool elevations, morphometric analysis of selected pools, and coring of pool sediments and peats. The sand plain east of the bog was first surveyed with a transit-level and staff, and then the bog surface level was surveyed from the south end to the center. At each survey point across the southern half of the bog the

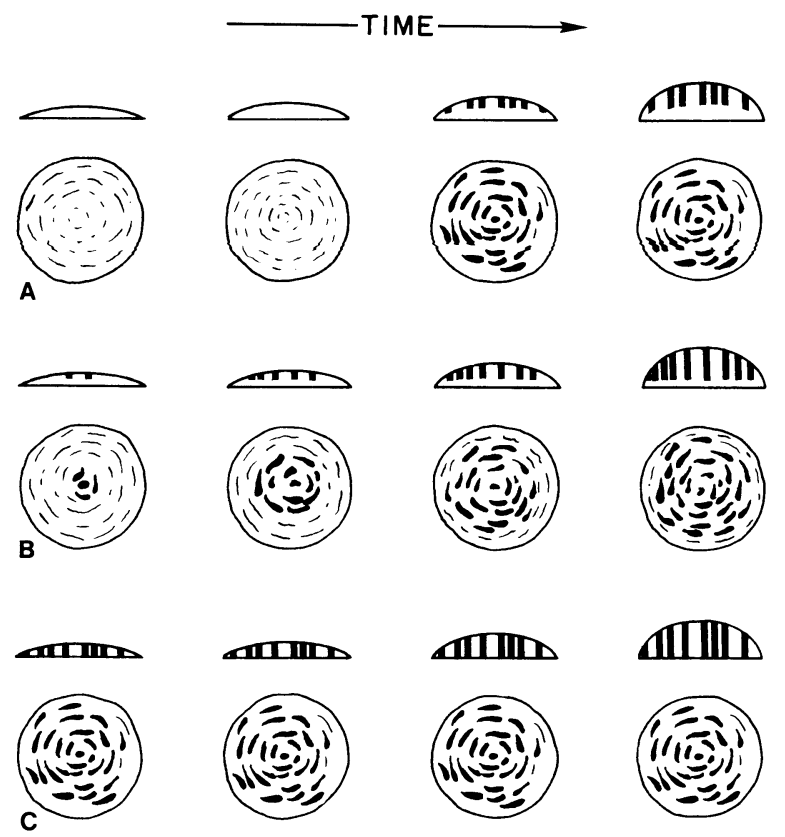

FIG. 5. Schematic representations of three models of bog landform development through time showing the formation of pools in plan view and cross section. In the allogenic model (A) pools are initiated synchronously across the bog in response to external environmental change, in the autogenic model (B) pools develop progressively across the mire from the center as controlled by characteristics of the mire (e.g., peat depth) and in the neutral model (C) pools are initiated at the time of bog formation. 
depth of the underlying peat was determined with a thin metal rod. At several points the peat stratigraphy was examined with a Russian peat corer.

Fifteen pools were studied morphometrically. Water depth was measured at 1-5-m intervals along the long axis and across the maximum width of each pool. Cores $5 \mathrm{~cm}$ in diameter were obtained from the deepest part of eight pools by sampling from a small rubber raft. The uppermost organic ooze (gyttja) was collected in a clear plastic tube provided with a piston so that the water: gyttja contact was preserved; the lower sediments were collected with a square-rod piston corer (Wright 1967). The loose gyttja was extruded in 2-cm increments into plastic bags. The remainder of the core was wrapped in plastic and aluminum foil for transport to the laboratory.

The cores were sampled and analyzed at the Department of Quaternary Geology, University of Lund. Each core was split in half lengthwise, and one-half was cut into increments of 2-5 cm, which were washed through two sieves (100- and $250-\mu \mathrm{m}$ mesh) to obtain coarse and fine fractions for macrofossil analysis. Samples were taken for radiocarbon dating of the basal peat at 15 locations. The basal $3-8 \mathrm{~cm}$ of peat was uniformly made up of very dark and well-decomposed silty material that frequently contained charcoal. The dated sample was taken just above this layer. For each of the eight pool cores the contact between gyttja and underlying peat was first identified. The uppermost $5 \mathrm{~cm}$ of peat and the adjacent lowermost $5 \mathrm{~cm}$ of gyttja were sampled for radiocarbon dating. Samples were submitted to the radiocarbon laboratory at the Department of Quaternary Geology at Lund University for dating (Hakansson 1986, 1987).

At Nittenmossen cores were taken every $50 \mathrm{~m}$ on a transect from near the center of the mire to the margin. The peat stratigraphy was described in the field and six basal samples were collected for dating at Lund. The Russian corer was used for examining the stratigraphy at many places across the mire.

\section{RESUlts \\ Bog development}

As documented by the basal radiocarbon dates Hammarmossen and Nittenmossen developed through continuous horizontal and vertical accumulation of peat (Figs. 2 and 3; Table 1). Both mires formed $\approx 6000 \mathrm{BP}$ with peat initiation near the center of the mire and in the region of what is now the deepest peat. Horizontal expansion occurred concentrically. At Nittenmossen there is an indication that the rate of horizontal extension decreased with time (Fig. 6A). At Nittenmossen the basal age : depth curve is approximately linear (Fig. 6B) whereas at Hammarmossen it is concave (Fig. 7A).

\section{Pool characteristics}

The bog pools at Hammarmossen exhibit considerable variation in size, shape, and morphometry (Figs.
1 and 8). Pools range from $<2 \mathrm{~m}$ in length to $>100$ $\mathrm{m}$. The largest pools, which are subcircular in outline, are positioned on gently sloping areas towards the center of the mire. More nearly linear pools are aligned along contours between the crest of the mire and the margin. The marginal slopes contain elongated hollows that are intermittently filled with water and support carpets of Sphagnum cuspidatum and S. papillosum. Coalescence of adjacent pools and hollows is recognizable from the scalloped and complex outlines (Fig. 1) and from the appearance in cross section of double basins separated by an intervening ridge (e.g., pools 4 and 5 in Fig. 8). Shape is therefore governed in part by slope position and in part by such dynamic processes as coalescence and expansion.

Three main types of pool morphometry were observed in cross section: steep sides and flat bottom (pools 6 and 7; Fig. 8), an undulating bottom (pools 1, 2,3 , and 8 ), and two basins separated by a sharp ridge of peat (pools 4 and 5). Most pools have very welldefined and solid banks. The seasonal maximum water depth ranges from 40 to $240 \mathrm{~cm}$ and is generally correlated with pool age (Table 2, Fig. 9B). The water in all of the pools is colorless. Macrophytic pool vegetation is generally limited to Sphagnum cuspidatum growing along the margins or floating in the water, whereas diatoms and other algae comprise a major component of the gyttja sediment (S. Fritz, personal communication).

\section{Pool stratigraphies and age}

The sediment beneath pools consistently includes gyttja, ranging in thickness from 35 to $110 \mathrm{~cm}$, a sharp transition to Sphagnum peat, $25-85 \mathrm{~cm}$ thick, and a basal layer 5-8 cm thick of well-humified silty peat and mineral soil. The gyttja contains variable amounts of detritus of Sphagnum cuspidatum, sedge leaves, and pine needles and is distributed in a thick layer across the bottom of the pools. Rough estimates of the rates of peat accumulation below pools and sedimentation of gyttja in pools can be derived from the radiocarbon dates (Table 2), assuming constancy of rates and no compaction or subsequent decomposition (however, cf. Clymo 1984). Peat accumulation ranges from $\approx 9$ to $110 \mathrm{~cm} / 1000 \mathrm{yr}$, with most cores ranging from 33 to $90 \mathrm{~cm} / 1000 \mathrm{yr}$. Gyttja deposition has a narrower range of $20-60 \mathrm{~cm} / 1000 \mathrm{yr}$, with most pools ranging from 30 to $50 \mathrm{~cm} / 1000 \mathrm{yr}$.

The pools sampled are situated on portions of the mire that range from 2000 to $6000 \mathrm{yr}$ old, as interpolated from the isochrones drawn from 17 basal radiocarbon dates (Fig. 2; Foster et al. 1988). Based on the age of peat immediately below pool sediment the pools range from 1940 to $4200 \mathrm{yr}$ in age. Two pools occur in each of the periods from 2300 to $2400 \mathrm{BP}$ and 4000 to $4200 \mathrm{BP}$, and three pools date to the interval 2940-3060 BP. One pool has a date of formation of 1940 BP. 
TABLE 1. Radiocarbon dates from Hammarmossen and Nittenmossen bogs, Sweden. Paired dates from the upper peats and lower gyttja sediments beneath pools at Hammarmossen have been given the same core number. Errors quoted include standard deviations of count rates.

\begin{tabular}{|c|c|c|c|c|}
\hline Core number & Laboratory number & $\begin{array}{l}\text { Sample depth } \\
\text { (cm below water } \\
\text { or peat surface) }\end{array}$ & Material & $\begin{array}{l}\text { Radiocarbon date } \\
\text { (yr BP } \pm 1 \text { SD) }\end{array}$ \\
\hline \multicolumn{5}{|c|}{ Hammarmossen } \\
\hline 1 & Lu-2526 & $25-30$ & Basal peat & $20 \pm 45$ \\
\hline 2 & Lu-2527 & $105-110$ & Basal peat & $920 \pm 45$ \\
\hline 3 & Lu-2528 & $215-220$ & Basal peat & $2320 \pm 50$ \\
\hline 4 & Lu-2529 & $300-305$ & Basal peat & $3140 \pm 50$ \\
\hline 5 & Lu-2530 & $310-320$ & Basal peat & $3950 \pm 60$ \\
\hline 6 & Lu-2531 & $365-375$ & Basal peat & $5190 \pm 60$ \\
\hline 7 & $\mathrm{Lu}-2532$ & $365-375$ & Basal peat & $5240 \pm 60$ \\
\hline 8 & $\mathrm{Lu}-2533$ & $175-185$ & Basal peat & $2130 \pm 50$ \\
\hline 9 & Lu- 2534 & $335-345$ & Basal peat & $5820 \pm 60$ \\
\hline 10 & Lu-2535 & $235-245$ & Basal peat & $2390 \pm 50$ \\
\hline 11 & Lu-2536 & $130-140$ & Basal peat & $1450 \pm 45$ \\
\hline $12 a^{*}$ & $\mathrm{Lu}-2537$ & $90-100$ & Gyttja & $1300 \pm 45$ \\
\hline $12 \mathrm{~b}$ & $\mathrm{Lu}-2538$ & $100-110$ & Pool peat & $1940 \pm 50$ \\
\hline $13 \mathrm{a}$ & $\mathrm{Lu}-2539$ & $210-220$ & Gyttja & $2040 \pm 50$ \\
\hline $13 \mathrm{~b}$ & Lu-2540 & $220-225$ & Pool peat & $2390 \pm 50$ \\
\hline $14 \mathrm{a}$ & $\mathrm{Lu}-2541$ & $305-310$ & Gyttja & $3770 \pm 60$ \\
\hline $14 \mathrm{~b}$ & Lu-2542 & $310-315$ & Pool peat & $4200 \pm 60$ \\
\hline $15 \mathrm{a}$ & Lu-2543 & $290-300$ & Gyttja & $2580 \pm 50$ \\
\hline $15 \mathrm{~b}$ & Lu-2544 & $300-310$ & Pool peat & $4010 \pm 60$ \\
\hline 16 & $\mathrm{Lu}-2545$ & $310-315$ & Basal peat & $4130 \pm 60$ \\
\hline 17 & Lu-2822 & $365-375$ & Basal organic & $6540 \pm 70$ \\
\hline $18 \mathrm{a}$ & Lu-2823 & $302-307$ & Peat & $2710 \pm 50$ \\
\hline $18 \mathrm{~b}$ & Lu-2824 & $307-312$ & Peat & $2640 \pm 50$ \\
\hline $19 \mathrm{a}$ & Lu-2825 & $198-203$ & Gyttja & $1470 \pm 50$ \\
\hline $19 \mathrm{~b}$ & Lu-2826 & $203-208$ & Pool peat & $2940 \pm 50$ \\
\hline $20 \mathrm{a}$ & Lu-2827 & $270-275$ & Gyttja & $1780 \pm 50$ \\
\hline $20 \mathrm{~b}$ & $\mathrm{Lu}-2828$ & $275-280$ & Pool peat & $3060 \pm 50$ \\
\hline $21 \mathrm{a}$ & Lu-2829 & $250-255$ & Gyttja & $2230 \pm 50$ \\
\hline $21 \mathrm{~b}$ & $\mathrm{Lu}-2830$ & $255-260$ & Pool peat & $3030 \pm 50$ \\
\hline $22 \mathrm{a}$ & Lu-2831 & $219-224$ & Gyttja & $1860 \pm 50$ \\
\hline $22 \mathrm{~b}$ & Lu-2832 & $224-229$ & Pool peat & $2300 \pm 50$ \\
\hline 23 & $\mathrm{Lu}-2833$ & $95-100$ & Basal peat & $940 \pm 50$ \\
\hline \multicolumn{5}{|c|}{ Nittenmossen } \\
\hline A & Lu-2852 & $328-335$ & Basal peat & $4910 \pm 60$ \\
\hline $\mathrm{B}$ & $\mathrm{Lu}-2851$ & $340-347$ & Basal peat & $6070 \pm 70$ \\
\hline $\mathrm{C}$ & Lu-2853 & $293-300$ & Basal peat & $5450 \pm 60$ \\
\hline $\mathrm{D}$ & Lu-2854 & $237-244$ & Basal peat & $4290 \pm 60$ \\
\hline $\mathrm{E}$ & $\mathrm{Lu}-2855$ & $118-125$ & Basal peat & $2290 \pm 50$ \\
\hline $\bar{F}$ & Lu-2856 & $23-30$ & Basal peat & $520 \pm 50$ \\
\hline
\end{tabular}

$* \mathrm{a}$ and $\mathrm{b}$ are two samples from the same core.

Pool age is closely related to both basal depth (Fig. 7A), and basal age (Fig. 9A), and more loosely to pool depth (Fig. 9B). Pool ages fall on a concave line against basal peat depth that closely parallels the curve for basal age and depth (Fig. 7A, B). The basal age below the oldest pool cored is $\approx 4800 \mathrm{BP}$ with a pool age of 4010 BP. The youngest pool cored, formed in 1940 $\mathrm{BP}$, is underlain by basal peat $\approx 2000 \mathrm{yr}$ old. The mean interval between peat initiation and pool formation was $550 \mathrm{yr}$, with a maximum of $\approx 1100 \mathrm{yr}$. The pools apparently form in a relatively short time following peat initiation and then persist for many thousands of years.

The onset of gyttja sedimentation shows a much looser relationship to basal depth and age (Fig. 9C). This is partly a consequence of the variable length of the temporal hiatus that separates pool formation (based on the age of the uppermost peat) and the onset of gyttja deposition (based on the age of the lowermost gyttja; Fig. 10). In five pools there was a hiatus $>600$ yr (640-1470 yr) and in three pools the difference was $350-440 \mathrm{yr}$. The duration of the hiatus does not appear to be related to any obvious characteristic of pool morphometry, slope position, age, or sediment characteristics.

\section{DISCUSSION}

Mires are dynamic ecosystems that change progressively by vertical and horizontal accumulation of peat and subsequent variation in hydrology, chemistry, and vegetation composition. Thus, although system characteristics and processes may vary within a narrow range over the period of an ecological or hydrological field study they may change significantly over the time 

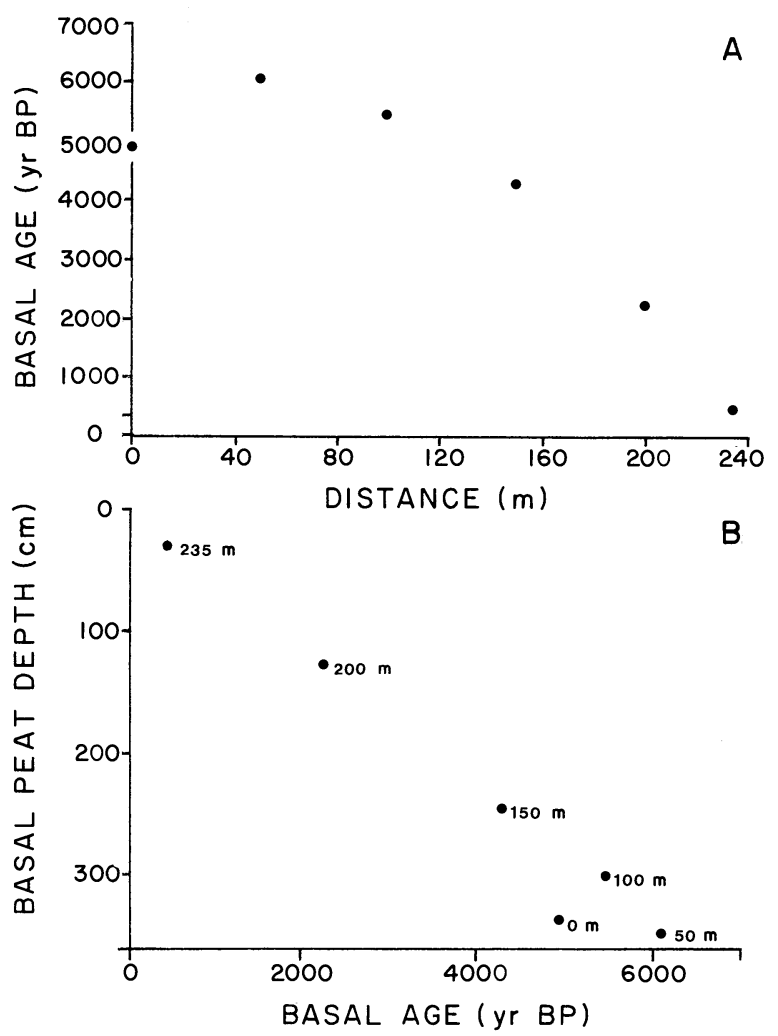

FIG. 6. Graphs from Nittenmossen showing (A) the relationship between the age of basal samples and distance along the transect from the center to the margin of the bog (see Fig. 3 ), and (B) the relationship between depth of basal samples and radiocarbon age.

scale of paleoecological reconstructions (Ivanov 1981). The significant question considered in the current study is: To what extent are the major changes recorded in peat stratigraphy a signal of autogenic development of the mire system and to what extent are they a result of allogenic, primarily climatic factors? The conclusions are of interest not only for their bearing on paleoenvironmental reconstruction but for their relevance to understanding ecosystem development and integration. In order to understand the broader context for landform development, it is therefore essential to explore the formation and dynamics of entire bog ecosystems.

\section{Bog development: empirical results and theoretical models}

Hammarmossen and Nittenmossen were formed $\approx 6000 \mathrm{BP}$. Basal radiocarbon dates at the two sites suggest a rather steady rate of horizontal spread from a single initial locus, with no marked alteration through time (Figs. 2 and 3). The relationship between age and depth for basal samples at the two sites comprises a concave or a linear function (Figs. 6 and 7). The absence of abrupt changes along these curves suggests continuous bog development. The results unequivo- cally support the single locus model of bog development discussed above (Model C, Fig. 4).

The interpreted history of development for these bogs also conforms closely to that derived from recent hydrodynamic models of bog formation (Clymo 1978, 1984, Ingram 1978). The models in turn describe changes in bog shape and hydrology that may have direct application towards understanding landform changes on the mires.

The simplest models assume (1) initiation from a central locus, (2) development across a flat nearly impermeable substrate, (3) peat groundwater discharge around the perimeter, and (4) constant mositure parameters (Clymo 1978, 1984). Under these conditions $U$, peat groundwater discharge, is defined by the hydrological budget as

$$
P-E-U-G-W=0
$$

where $P=$ precipitation, $E=$ evapotranspiration, $G=$ groundwater leakage through the substratum (considered to be insignificant relative to $U$ ), and $W=$ change in storage. Ingram $(1982,1983)$ has shown that the water table of a raised bog is maintained by impeded drainage and dynamic equilibrium between recharge and supply and may be described by equations for
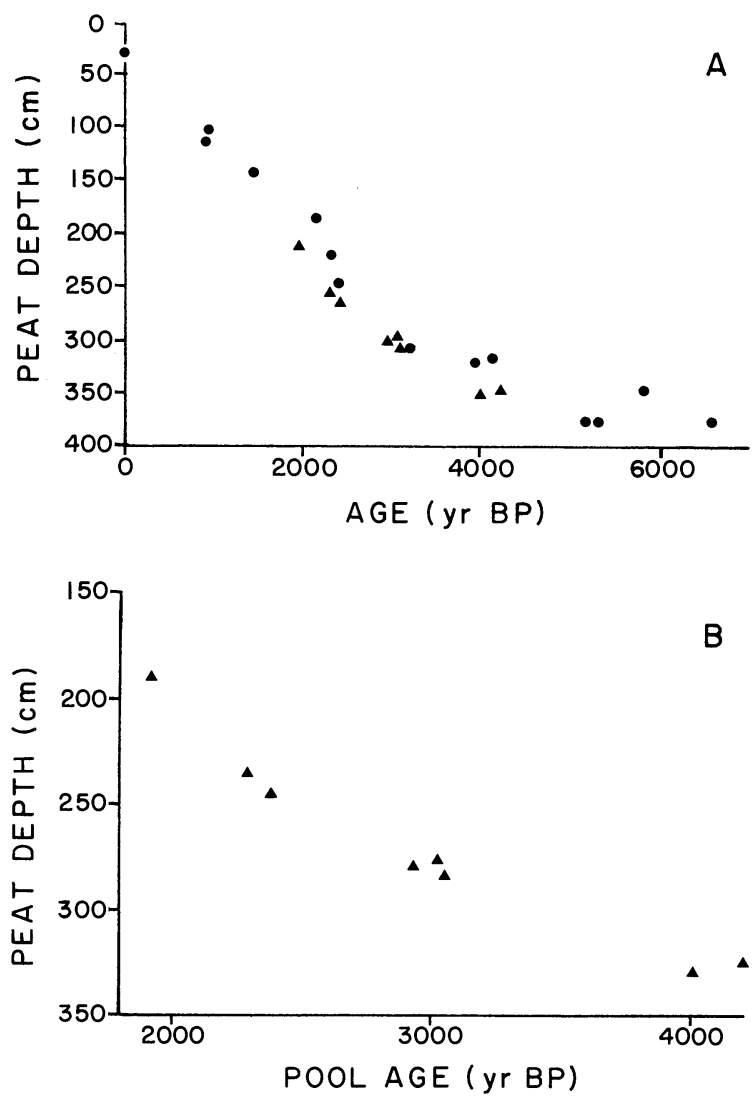

FIG. 7. Graphs from Hammarmossen showing (A) the relationship between the depth of basal samples and their age and (B) the relationship between basal depth and pool age. 

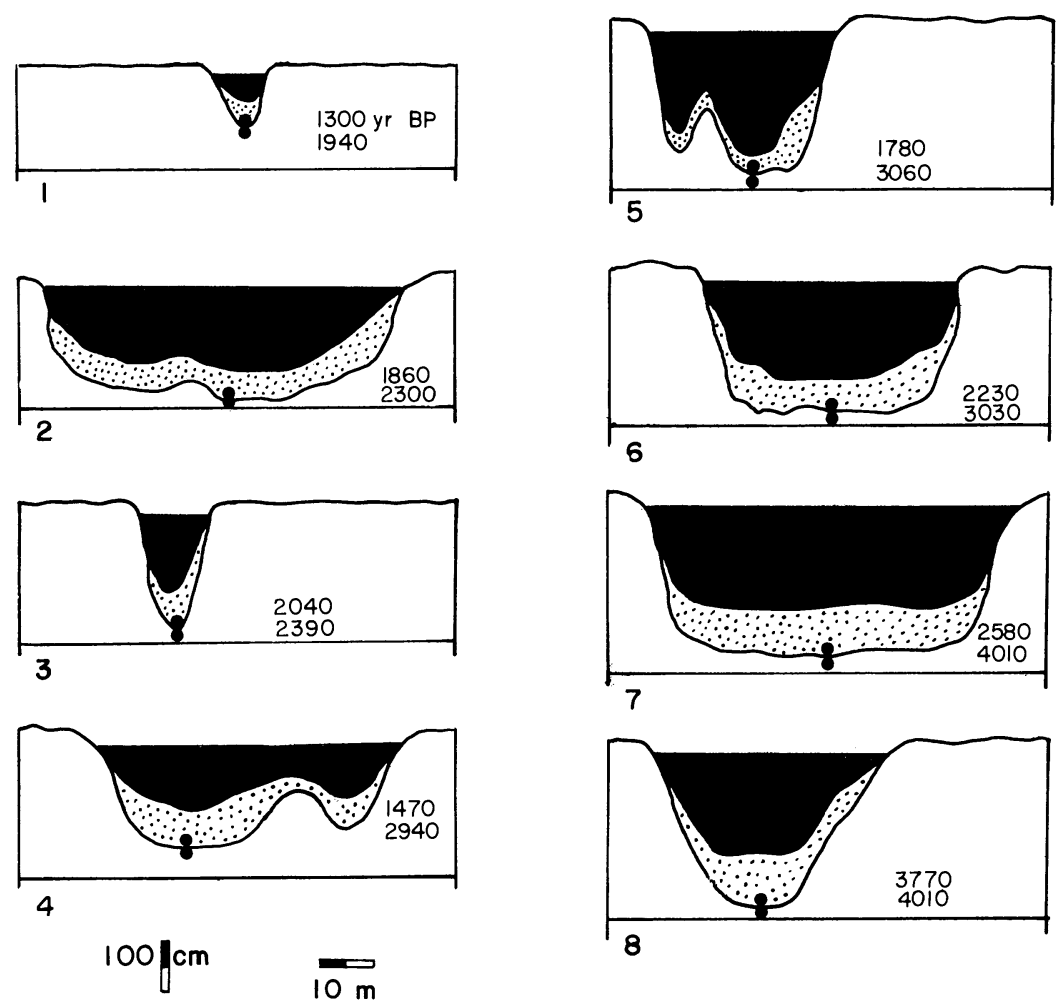

FIG. 8. Cross-sectional diagrams of the pools investigated in this study (numbered at lower left each diagram) showing depth of water (black), thickness of gyttja sediment (stippled), and depth of peat (white). Radiocarbon dates are given for samples $(\bullet)$ taken at the base of the gyttja sediment and the top of the peat.

groundwater mounds (cf. Marino 1974). Shape and size of groundwater mounds may be described as hemielliptical in cross section, following the equation

$$
U^{*} / k=H^{2} /\left(L l-l^{2}\right)
$$

where $U^{*}=$ the value of $U$ in long droughts (R. S. Clymo, personal communication), $H=$ height of bog surface, $L=$ bog radius, $l=$ distance from the bog margin, and $k=$ hydraulic conductivity. From this equation the maximum water height at the bog center should be

$$
H=\left(U^{*} L^{2} / k\right)^{1 / 2} .
$$

As demonstrated by Clymo (1984), if $U^{*}$ and $k$ are constant, then for a bog of given radius $L_{x}$ the height will accumulate to $H_{x}$ with a hemi-elliptical water table. If there is no physical obstruction the mire will spread horizontally, and new values of $L$ and $H$ will be reached. Although there is no direct hydrological constraint on further increase in bog size, decay processes will eventually limit height to a steady state $\left(H_{\max }\right)$. This will occur at the point where production, in terms of organic matter reaching the catotelm (sensu Ingram 1982) of the mire, is equalled by the cumulative slow decay throughout the catotelm (Damman 1979,

\begin{tabular}{|c|c|c|c|c|c|c|c|c|c|c|}
\hline Pool no. & $\begin{array}{l}\text { Maxi- } \\
\text { mum } \\
\text { length } \\
(\mathrm{m})\end{array}$ & $\begin{array}{l}\text { Maxi- } \\
\text { mum } \\
\text { width } \\
(\mathrm{m})\end{array}$ & $\begin{array}{l}\text { Maxi- } \\
\text { mum } \\
\text { water } \\
\text { depth } \\
(\mathrm{cm})\end{array}$ & $\begin{array}{l}\text { Tran- } \\
\text { sition } \\
\text { gyttja/ } \\
\text { peat } \\
(\mathrm{cm})\end{array}$ & $\begin{array}{c}\text { Basal } \\
\text { depth } \\
\text { (cm) }\end{array}$ & $\begin{array}{l}\text { Basal } \\
\text { age } \\
\text { (est. yr } \\
\text { BP) }\end{array}$ & $\begin{array}{l}\text { Pool } \\
\text { age } \\
\left({ }^{14} \mathrm{C} \text { yr }\right. \\
\text { BP })\end{array}$ & $\begin{array}{c}\text { Gyttja } \\
\text { age } \\
\left({ }^{14} \mathrm{C} \text { yr }\right. \\
\text { BP })\end{array}$ & $\begin{array}{l}\text { Basal peat } \\
\text { accum. } \\
\text { rate } \\
(\mathrm{cm} / 1000 \\
\text { yr) }\end{array}$ & $\begin{array}{c}\text { Gyttja } \\
\text { accum. } \\
\text { rate } \\
(\mathrm{cm} / 1000 \\
\text { yr) }\end{array}$ \\
\hline 2 & 37 & 17 & -200 & -310 & -325 & 4800 & 4200 & 3770 & 25.00 & 29.18 \\
\hline 1 & 62 & 38 & -197 & -295 & -330 & 4700 & 4010 & 2580 & 50.72 & 37.98 \\
\hline 6 & 35 & 13 & -240 & -275 & -285 & 4200 & 3060 & 1780 & 8.77 & 19.66 \\
\hline 5 & 50 & 16 & -130 & -203 & -280 & 3800 & 2940 & 1470 & 44.91 & 49.66 \\
\hline 7 & 45 & 25 & -190 & -260 & -277 & 3400 & 3030 & 2230 & 45.95 & 31.39 \\
\hline 3 & 12 & 9 & -150 & -225 & -245 & 3000 & 2390 & 2040 & 32.79 & 36.76 \\
\hline 8 & 63 & 14 & -165 & -224 & -235 & 2400 & 2300 & 1860 & 110.00 & 31.72 \\
\hline 9 & 9 & 5 & -40 & -100 & -190 & 2000 & 1940 & 1300 & 73.43 & 46.15 \\
\hline
\end{tabular}

TABLE 2. Characteristics of pools on Hammarmossen Bog, Sweden. Pools are arranged in order of decreasing basal age. 

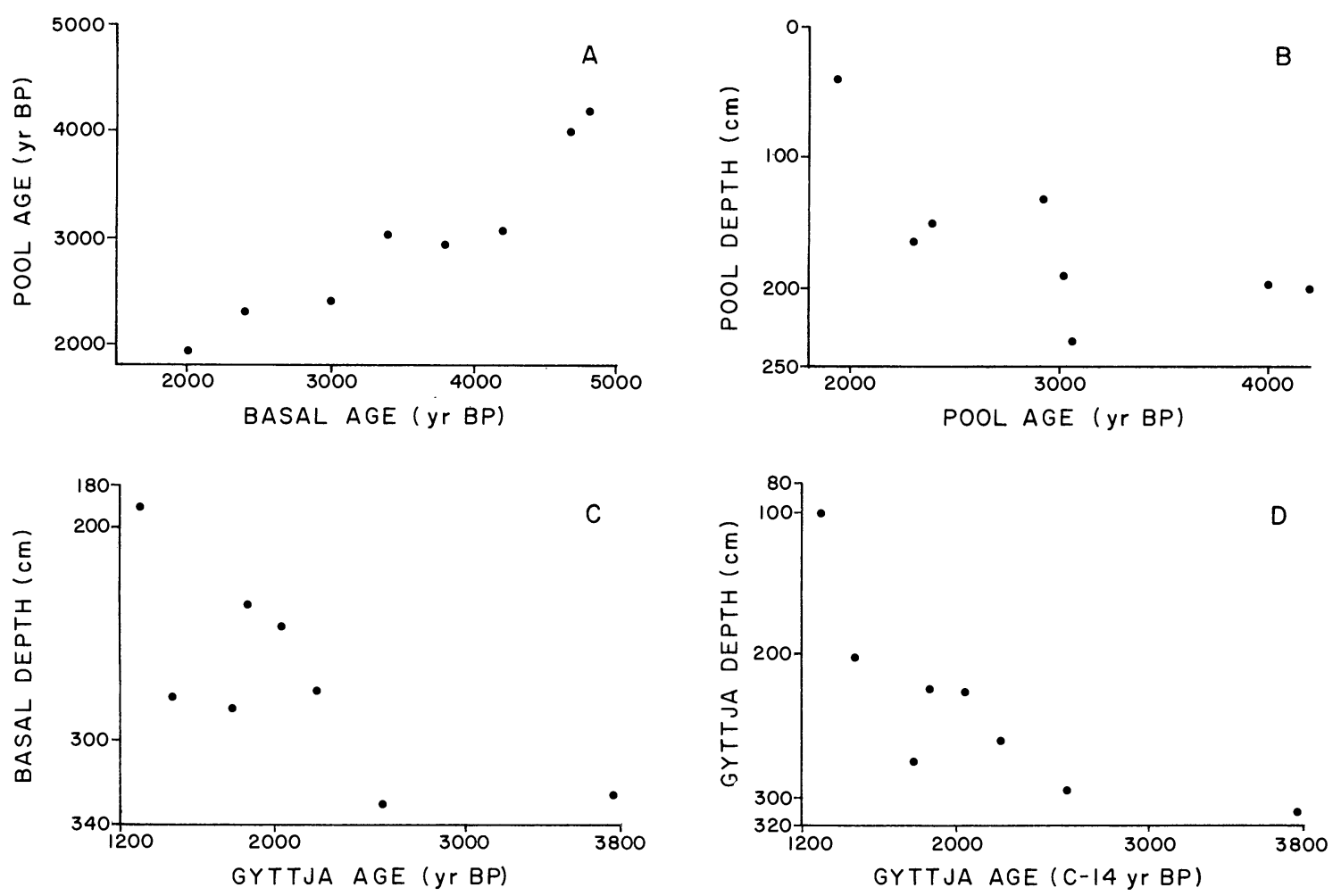

FIG. 9. Graphs showing the relationships between (A) basal age and pool age, (B) pool age and pool depth, (C) gyttja age and basal depth, and (D) gyttja age and gyttja depth at Hammermossen.

Clymo 1984). At $H_{\max }$ the horizontal extent of the mire $\left(L_{\max }\right)$ will be controlled by hydrology.

In the absence of external environmental change this model describes the consequences of peat accumulation in terms of changing morphology and age-relations on a growing mire. Starting from a central locus a raised bog may then spread concentrically across a flat plain as it increases in height. As the mire grows, its gross

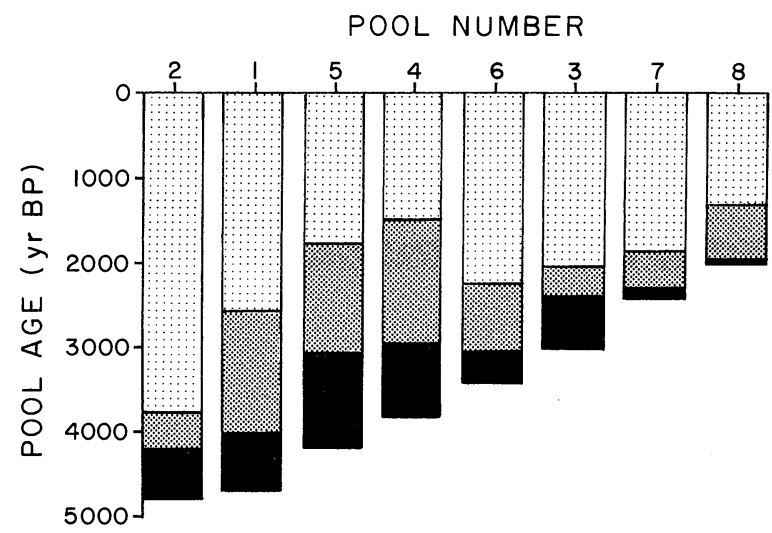

FIG. 10. The stratigraphy of each pool is presented showing the duration of peat accumulation (black), the hiatus between pool formation and gyttja sediment deposition (dark stippled), and the duration of sediment deposition (light stippled). morphology should change in conformance with the hemi-elliptical groundwater equation with the margins becoming steeper and the center becoming flatter and broader (Ingram 1982). As a consequence of slow decay throughout the catotelm the surface produced at any given time should gradually sink down through time (Fig. 11). Curves of age vs. depth should therefore be concave for both a single core (Aaby and Tauber 1975, Clymo 1984) and for a series of basal dates taken from the center of a concentric mire to the margin (Fig. 12). At Hammarmossen the concave curvilinearity of the basal dates vs. depth follows this pattern. At Nittenmossen this plot is more nearly linear.

The developmental pattern described by hydrodynamic modelling and conforming generally to the results from Hammarmossen and Nittenmossen (sequence of basal dates; curve of basal age vs. depth) suggest a long continuity of general processes and hydrology on bogs (Clymo 1984). The hydrology, in particular the depth to water table and seepage gradient, should be largely controlled by this gross morphology, especially the topographic gradient (Ivanov 1981, Kurimo 1984). Steep marginal slopes would be expected to have steeper seepage gradients and greater depth to the water table than the increasingly broad and more level bog expanse (Rycroft 1971, Damman and Donham 1981, Bragg 1982). Likewise, the distribution of vegetation and microtopographic features would be ex- 


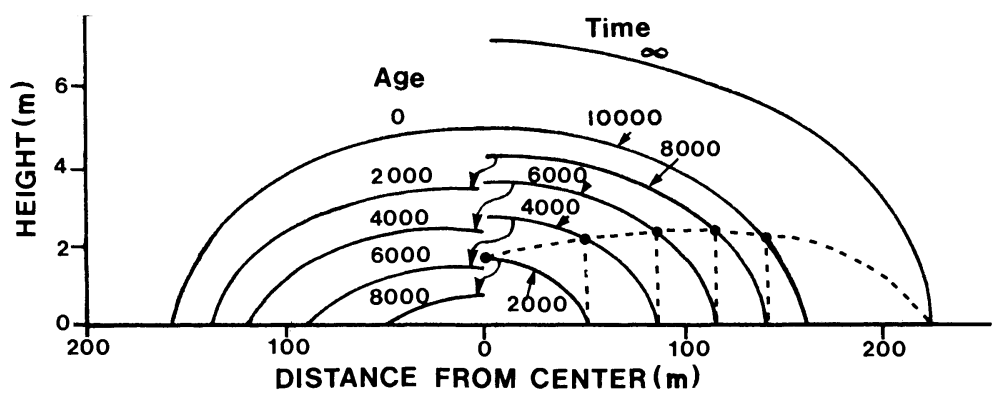

FIG. 11. Idealized curves of development through time for a 10000 -yr-old bog, showing, on the right-hand side, the bog surface at 2000-yr intervals after bog formation and, on the left-hand side, the current level of former surfaces at 2000-yr intervals. The dashed line connects the height of each marginal location after $2000 \mathrm{yr}$ of peat accumulation and shows that peat accumulation rate increases from the center towards the margin and then decreases right before the margin. Modified from Clymo (1984).

pected to have a regular distributional pattern that follows these radial changes in depth to the water table (Ingram 1983). Thus, although any given area of the mire changes significantly with time and with its relative position on the mire, the entire mire maintains similar dynamic processes through time. This understanding of local and broad-scale change can be applied to the interpretation of landform dynamics.

\section{Pattern and timing of pool formation}

At Hammarmossen radiocarbon dates from the top of the peat beneath the gyttja of eight pools show that these landforms developed from 4200 to $1900 \mathrm{BP}$. The dates form a concave curve against peat depth and closely parallel the basal age : depth curve (Fig. 7). Pool formation has been active during a large portion of the developmental history of the bog and is correlated with the depth and age of the underlying peat.

These results appear to be inconsistent with the allogenic and neutral models of bog-pool development but are consistent with the autogenic model and suggest that a major factor controlling pool formation may have been the developmental processes of the bog massif, namely horizontal extension and vertical accumulation of peat. Pools have developed consistently from the bog center to the margin in accordance with declining age and depth of peat in this direction. This is in agreement with field observations of the current process of pool formation. The marginal $30-40 \mathrm{~m}$ of the mire, which forms a steep descent to the forested outwash plain, has a rather homogeneous vegetation of Sphagnum, dwarf shrubs, and Pinus sylvestris over a peat surface with little microtopography (Fig. 1). Just upslope from this steep margin, where the surface levels slightly, the trees clump into apparently random patches. The small openings between clumps are slight depressions, some of which contain standing water during wet periods. Slightly farther upslope these wet patches become elongated into sublinear hollows parallel to the contours. Growth of vascular plants is sparse because of the wetness, and a loose and deep cover of Sphagnum cuspidatum develops. With more persistent flooding the Sphagnum cover apparently degenerates (cf. Boatman 1972), and the peat beneath begins to decompose, resulting in open water. As the surrounding hummocks rise through peat accumulation the water in the pools becomes deeper and gyttja sedimentation seals the pool bottom. The difference between the radiocarbon dates for the top of the peat and the base of the overlying gyttja is a measure of the hiatus between pool formation and gyttja sedimentation plus the extent that peat may be removed by decompositional and erosional processes (Seppälä and Koutaniemi 1985, Foster and Fritz 1987).

The basal dates and field observations may be related back to the hydrodynamic models that suggest that the

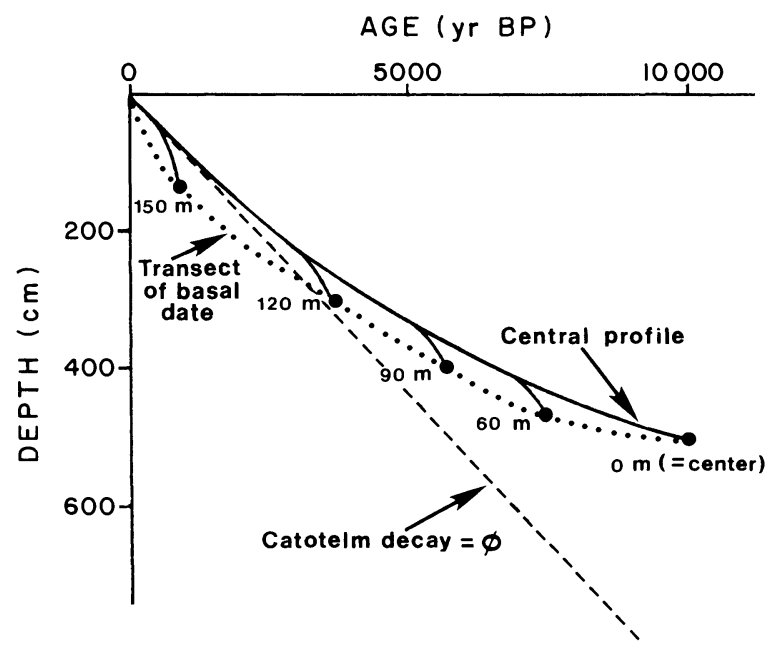

FIG. 12. Idealized curve from the hydrodynamic model of bog development showing the concave relationship between depth and age for a peat core taken from the center of a bog. Age-depth curves $(\longrightarrow)$ for other locations at a distance from the center are labelled. The dotted line $(\cdots \cdots)$ connecting these curves shows the relationship between age and depth for a transect of basal samples taken from the margin into the center of a bog. The dashed line (-- ) is the linear relationship expected if accumulation is constant and no decay or compaction occurs in the catotelm. Modified from Clymo (1984). 

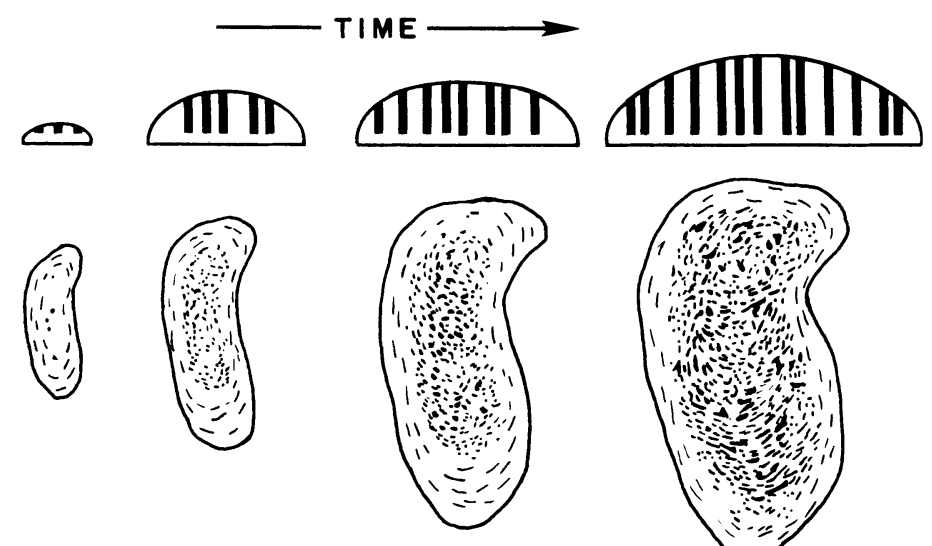

FIG. 13. Schematic reconstruction of the historical development of Hammarmossen showing plan view and cross-sectional view. The mire was initiated from a central locus and expanded outward and upward. Hummock-hollow patterns occupy steep marginal slopes and pools develop on deeper, more level central areas. Pool age and depth decreases from the center to the margin.

development of the bog is accompanied by changes in bog structure and hydrology. At any given time the vegetation and landform pattern conforms to the gross morphology and water table relations of the bog. Steep well-drained marginal slopes with a relatively great depth to the water table support linear, hummock and hollow structures. Hollows become deeper and broader progressively towards the center of the mire, thus pools occur on gentler slopes with a higher water table. However, as the bog actively spreads, marginal locations accumulate peat more rapidly than the central mire expanse (Clymo 1984). Therefore, for any specific location in the mire this leads to a change in slope from relatively steep to progressively more level as peat accumulates and the margin migrates outward (Fig. 11; Ingram 1983). Through time the small linear hollows initiated near the bog margin develop into pools that deepen and broaden as the mire continues to expand outward and upward (Fig. 13).

The results from this study suggest that landform development, at least on an unconfined bog capable of expansion as well as vertical growth, may be primarily controlled by the autogenic changes occurring during bog development. In comparison with the significant hydrological changes (depth to water table, thickness of the acrotelm, changes in seepage gradients) driven by changing bog shape, the effects of such extensive factors as precipitation/evaporation ratios appear to be relatively slight.

\section{Implications for stratigraphic study and environmental reconstruction}

The lessons from this study concerning the stratigraphic reconstruction of past environments are manifold. Major changes in landscape appearance and landform dynamics may have occurred on these raised bogs primarily as a result of autogenic processes. Presumably, many other changes in stratigraphy (e.g., degree of humification, peat structure, peat composition) may also arise in response to autogenically controlled hydrological conditions. Allogenic processes should therefore be interpreted as an overlay on this internal signal and can be understood only after the internal signal has been accounted for. For example, in the current study of Hammarmossen the dates within the pool age : basal-depth curve may be divided into four groups (4000-4200, 2940-3060, 2300-2390, and 1940 BP). It is possible that these clusters may represent some response to fluctuations in moisture availability. This response, however, is superimposed on the major signal of autogenic bog development.

In another regard it is clear that the examination of a very limited number of basal peats, pools, or hollows may provide a misleading interpretation of landform development on a mire. Basal dates from mires have often been used as indicators of major environmental change: e.g., change to climatic conditions suitable for peat accumulation (cf. Moore 1986) or upland modification by humans (Moore 1973). In the case of Hammarmossen or other concentrically expanding bogs, the majority of basal dates provide no environmental information; they only mark the contemporaneous extent of ecosystem development. However, the oldest dates from the center of the mires do mark the onset of peatland initiation. At Hammarmossen and Nittenmossen the central dates of $6000 \mathrm{BP}$ coincide with a known period of lower lake levels in southern Sweden (Digerfeldt 1988). Additional studies will be required to determine whether the history of moisture availability in central Sweden was different from that farther south, or whether peatland initiation was unrelated to changing water balance and reduced rates of decomposition at these sites. Similarly, the timing of pool initiation provides little direct evidence of climate change or landform stability. Many studies have discussed the relative longevity and age of pools, with 
considerable disagreement (Ratcliffe and Walker 1958, Moore 1977, Sakaguchi et al. 1982, Smart 1982). The Hammarmossen results support those studies suggesting that pools of all ages and landforms in all stages of development can occur on mires (Nichols 1918, Kuznetsov 1986).

\section{Pool formation and dynamics}

This study contributes to answering the question of landform dynamics, in addition to addressing the broader implications of the driving forces behind these dynamics. During this research it has been assumed that pool development is the result of biological processes under hydrological control. This conforms to the general interpretation of many researchers (Sjörs 1948, Ratcliffe and Walker 1958, Moore 1977, Smart 1982) and is supported by detailed studies (Ivanov 1981, Kuznetsov 1986, Foster and Fritz 1987). The current study adds the observation that the hydrological and geomorphological context in which pools form changes throughout their development.

Pools are initiated as hollows on relatively steep slopes over shallow peat. As the mire develops the hollows gradually develop into pools (Sernander 1908, Boatman 1983). This evidently occurs as a result of two processes. Presumably the rate of peat accumulation in the hollows is less than that in the adjacent hummock, and therefore the hollow surface decreases in height above the water table (Kashimura and Tachibana 1982, Boatman 1983, Kuznetsov 1986). This is supported by studies of production/decomposition rates in hummocks, lawns, and hollows (Clymo 1970, Clymo and Reddaway 1974, Pakarinen 1978, T. Moore, in press), by stratigraphic studies showing the gradual progression from hollow to pool (Moore 1977, Smart 1982, Foster and Glaser 1986, Foster and Fritz 1987) and by long-term observations (Mets 1982, Boatman 1983). In addition, and reinforcing this trend, the mire around the hollow presumably becomes more level and the general water table rises through time (Ingram 1982). As the surface level of the hollow decreases relative to the water table, the plants gradually become weakened and are ultimately replaced by open-water conditions.

The microtopographical development of small-scale features on the mire must therefore be viewed within the geomorphological perspective of the broad-scale peat mass. This conforms to Aario's (1932) distinction between Kleinformen and Grossformen. As the mire becomes flatter and pools develop from hollows, the narrow hollows may also expand laterally and coalesce with adjacent areas to form broader pools. The broadbased pools on the central expanse of the mire are derived from initial hollows that were elongated along a much steeper slope.

\section{ACKNOWLEDGMENTS}

We gratefully acknowledge the assistance of $\mathrm{M}$. Thelaus with the fieldwork, the introduction to the Swedish landscape by $\mathrm{H}$. and G. Sjörs, the hospitality and support of Professors N. Malmer and B. Berglund at the University of Lund, the helpful comments of B. Aaby, R. S. Clymo, H. A. P. Ingram, N. Malmer, G. Motzkin, and M. Santelmann on the manuscript, and the technical assistance of B. Flye. Research support was provided by the National Science Foundation (BSR 8806386), the Swedish National Research Council, and the Swedish Royal Society. Contribution Number 399 from the Limnological Research Center, University of Minnesota.

\section{Literature Cited}

Aaby, B. 1986. Palaeoecological study of mires. Pages 145164 in B. E. Berglund, editor. Handbook of Holocene palaeoecology and palaeohydrology. John Wiley \& Sons, New York, New York, USA.

Aaby, B., and H. Tauber. 1975. Rates of peat formation in relation to degree of humification and local environment, as shown by studies of a raised bog in Denmark. Boreas 4: $1-17$.

Aario, L. 1932. Pflanzentopographische und paläogeographische Mooruntersuchungen in Nord Satakunta. Communications Instituti Forestalis Fenniae 17:1-189.

Aartolahti, T. 1967. On dating the genesis of peat banks and hollows in the raised bogs of southwestern Finland. Comptes Rendus de la Société Géologique de Finlande 39: 71-86.

Barber, K. E. 1981. Peat stratigraphy and climatic change. Balkema, Rotterdam, The Netherlands.

Berglund, B. E., G. Lemdahl, B. Liedberg-Jönsson, and T. Persson. 1984. Biotic response to climatic changes during the time span 13000-10000 B.P. - a case study from southwest Sweden. Pages 25-36 in N.-A. Mörner and W. Karlen, editors. Climatic changes on a yearly to millenial basis. D. Reidel, Dordrecht, The Netherlands.

Birks, H. J. B., and H. Birks. 1980. Quaternary paleoecology. Edward Arnold, London, England.

Blytt, A. G. 1876. Essays on the immigration of the Norwegian flora during alternating rainy and dry periods. A. Cammermeyer, Christiania, Norway.

Boatman, D. J. 1972. Pools on blanket mires in Scotland. Pages 111-119 in Proceedings of the Fourth International Peat Congress, Otaniemi, Finland.

. 1983. The Silver Flowe National Nature Reserve, Galloway, Scotland. Journal of Biogeography 10:163-274.

Bragg, O. M. 1982. The acrotelm of Dun Moss. Plants, water and their relationships. Dissertation. University of Dundee, Dundee, Scotland.

Casparie, W. A. 1969. Bult- und Schlenkenbildung im Hochmoortorf. Vegetatio 19:146-180.

Clymo, R. S. 1970. The growth of Sphagnum: methods of measurement. Journal of Ecology 58:13-49.

1978. A model of peat bog growth. Pages 187-223 in O. W. Heal and D. F. Perkins, editors with W. M. Brown. Production ecology of British moors and montane grasslands. Springer-Verlag, Berlin, Germany.

. 1984. The limits to peat bog growth. Philosophical Transactions of the Royal Society of London $\mathbf{B}, 303: 605$ 654.

Clymo, R. S., and E. J. F. Reddaway. 1974. Growth rate of Sphagnum rubellum Wils. on Pennine blanket bog. Journal of Ecology 62:191-196.

Conway, V. M. 1948. Von Post's work on climatic rhythms. New Phytologist 47:220-237.

Damman, A. W. H. 1979. Geographic patterns in peatland development in eastern North America. Pages 213-228 in Proceedings of the International Symposium on Classification of Peat and Peatlands, Classification of Mires and Peats. Hyytiälä, Finland.

Damman, A. W. H., and J. J. Donham. 1981. Vegetation and habitat conditions in Western Head Bog, a southern 
Nova Scotian plateau bog. Canadian Journal of Botany 59: 1343-1359.

Digerfeldt, G. 1988. Reconstruction and regional correlation of Holocene lake-level fluctuations in Lake Bysjön, South Sweden. Boreas 17:165-182.

Drury, W. H. 1956. Bog flats and physiographic processes in the upper Kuskokwim River region, Alaska. Contributions from the Gray Herbarium of Harvard University 178.

Dupont, L. M. 1986. Temperature and rainfall variation in the Holocene based on comparative palaeoecology and isotope geology of a hummock and a hollow (Bourtangerveen, The Netherlands). Review of Palaeobotany and Palynology 48:71-159.

Foster, D. R., and S. C. Fritz. 1987. Mire development, pool formation, and landscape processes on patterned fens in Dalarna, central Sweden. Journal of Ecology 75:409-437.

Foster, D. R., and P. H. Glaser. 1986. The raised bogs of south-eastern Labrador, Canada: classification, distribution, vegetation and recent dynamics. Journal of Ecology 74:47-71.

Foster, D. R., H. E. Wright, M. Thelaus, and G. A. King. 1988. Bog development and landform dynamics in central Sweden and south-eastern Labrador, Canada. Journal of Ecology 76:1164-1185.

Frenzel, B. 1983. Mires-repositories of climatic information or self-perpetuating ecosystems? Pages 35-66 in A. J. P. Gore, editor. Ecosystems of the World 4A. Mires: swamp, bog, fen and moor. Elsevier, Amsterdam, The Netherlands.

Früh, J., and C. Schröter. 1904. Die Moore der Schweiz mit Berücksichtigung der gesamten Moorfrage. Beiträge Geologie Schweiz Geotechnisch Serien 3, Lief.

Godwin, H. 1946. The relationship of bog stratigraphy to climatic change and archaeology. Proceedings of the Prehistoric Society, Paper Number 1:1-11.

- 1954. Recurrence-surfaces. Danmarks Geologiske Undersøgelse 80:23-30.

. 1981. The archives of the peat bogs. Cambridge University Press, Cambridge, England.

Gore, A. J. P., editor. 1983. Mires: swamp, bog, fen, and moor. Elsevier, Amsterdam, The Netherlands.

Granlund, E. 1932. De svenska högmossarnas geologi. Sveriges Geologiska Undersökning C, 373:1-193.

Hakansson, S. 1986. University of Lund radiocarbon dates XIX. Radiocarbon 28:1111-1132.

1987. University of Lund radiocarbon dates XX Radiocarbon 29:353-379.

Ingram, H. A. P. 1978. Soil layers in mires: function and terminology. Journal of Soil Science 29:224-227.

- 1982. Size and shape in raised mire ecosystems: a geophysical model. Nature 297:300-303.

. 1983. Hydrology. Pages 67-158 in Mires: swamp, bog, fen, and moor. A: general studies. Elsevier, Amsterdam, The Netherlands.

Ivanov, K. E. 1981. Water movement of mirelands. In A. Thomson and H. A. P. Ingram, translated from the Russian. Vodoobmen $\mathrm{v}$ botonykh landshaftakh. Academic Press, London, England.

Jacobson, G. L., and R. H. W. Bradshaw. 1981. The selection of sites for paleovegetational studies. Quaternary Research 16:80-96.

Janssens, J. 1983. A quantitative method for stratigraphic analysis of bryophytes in Holocene peat. Journal of Ecology 71:189-196

Kashimura, T., and H. Tachibana. 1982. The vegetation of the Ozegahara Moor and its conservation. Pages 193-224 in Ozegahara: scientific researches of the Highmoors in central Japan. Japan Society for the Promotion of Science, Tokyo, Japan.

Kurimo, H. 1984. Simultaneous groundwater table fluctuation in different parts of virgin pine mires. Silva Fennica 18:151-186.
Kuznetsov, O. L. 1986. The structure and age of ridgehollow aapa mire complexes. University Joensuu, Publications of the Karelian Institute 79:73-79.

Lindsay, R., J. Riggall, and F. Burd. 1985. The use of smallscale surface patterns in the classification of British peatlands. Aquilo Ser Botanica 21:69-79.

Lundqvist, G. 1951. Beskrivning till jordartskarta över Kopparbergs län. Sveriges Geologiska Undersökning Series $\mathrm{Ca}, 21$.

1963. Beskrivning till jordartskarta över Gävleborgs län. Sveriges Geologiska Undersökning Series Ca, NR42.

Lundqvist, J. 1958. Studies on the Quaternary history and deposits of Värmland, Sweden. Sveriges Geologiska Undersökning Series C. Arsbok 52, Number 559:1-128.

. 1969. Beskrivning till jordartskarta över Jämtlands Län. Sveriges Geologiska Undersökning Number 45.

Marino, M. A. 1974. Growth and decay of groundwater mounds induced by percolation. Journal of Hydrology 22: 295-301.

Mets, L. 1982. Temporal changes in peatland ecosystems. Changes in a bog pool complex during an observation period of 17 years. Estonian Contributions to the International Biological Programme 9:128-134.

Moore, P. D. 1973. The influence of prehistoric cultures upon the initiation and spread of blanket bog in upland Wales. Nature (London) 241:350-353.

- 1977. Stratigraphy and pollen analysis of Claigh Moss, Northwest Scotland: significance for the origin of surface-pools and forest history. Journal of Ecology 65:375397.

397. 1986. Hydrological changes in mires. Pages 91-110 in B. E. Berglund, editor. Handbook of Holocene palaeoecology and palaeohydrology. John Wiley \& Sons, New York, New York, USA.

Moore, T. R. 1989. Plant production and decomposition in a subarctic patterned fen. Arctic and Alpine Research, in press.

Nichols, G. E. 1918. The vegetation of Northern Cape Breton Island, Nova Scotia. Transactions of the Connecticut Academy of Arts and Sciences 22:249-467.

Nilsson, T. 1983. The Pleistocene: geology and life in the Quaternary Ice Age. F. Enke Verlag, Stuttgart, Germany.

Osvald, H. 1923. Die Vegetation des Hochmoores Komosse. Svenska Växtsociologiska. Sällskapets Handlingar (Uppsala) 1:1-436.

Pakarinen, P. 1978. Production and nutrient ecology of three Sphagnum species in southern Finnish raised bogs. Annales Botanici Fennici 15:15-26.

Pearsall, W. H. 1956. Two blanket-bogs in Sutherland. Journal of Ecology 44:493-516.

Ratcliffe, D. A., and D. Walker. 1958. The Silver Flowe, Galloway, Scotland. Journal of Ecology 46:407-445.

Ruuhijärvi, R. 1960. Uber die regionale Einteilung der nordfinnischen Moore. Annales Botanici Societatis Zoologicae Botanicae Fennicae Vanamo 30:1-360.

Rycroft, D. W. 1971. On the hydrology of peat. Thesis. University of Dundee, Dundee, Scotland.

Sakaguchi, Y. 1979. Distribution and genesis of Japanese peatlands. Bulletin of the Department of Geography, University of Tokyo Number 11.

Sakaguchi, Y., Y. Saijo, A. Yagi, M. Hibino, and H. Sohma. 1982. Characteristics of deposits and genesis of pools. Pages 75-90 in Ozegahara: scientific researches of the Highmoors in central Japan, Tokyo. Japan Society for the Promotion of Science, Tokyo, Japan.

Schenk, E. 1966. Origin of string bogs. Pages 155-159 in Permafrost: proceedings of an international conference. National Academy of Sciences, Washington, D.C., USA.

Seppälä, M., and L. Koutaniemi. 1985. Formation of a string and pool topography as expressed by morphology, stratig- 
raphy and current processes on a mire in Kuusamo, Finland. Boreas 14:287-309.

Sernander, R. 1908. On the evidences of Postglacial changes of climate furnished by the peat-mosses of Northern Europe. Geologiske Förensignens 30:465-473.

Sjörs, H. 1948. Myrvegetation i Bergslagen. Acta Phytogeographica Suecica 21:1-299.

. 1983. Mires of Sweden. Pages 220-253 in A. J. P. Gore, editor. Mires: swamp, bog, fen, and moor 4B. Regional studies. Elsevier, Amsterdam, The Netherlands.

Smart, P. J. 1982. Stratigraphy of a site in the Munsary Dubh Lochs, Caithness, northern Scotland: development of the present pattern. Journal of Ecology 70:549-559.

Tolonen, K. 1971. On the regeneration of North-European bogs. I. Klaukkala Isosuo in southern Finland. Acta Agralia Fennici 123:143-166.

Tolonen, K., P. Huttunen, and H. Jungner. 1985. Regeneration of two coastal raised bogs in eastern North America.
Annales Academiae Scientiarum Fennicae-Series A. III. Geologica-Geographica 139:1-51.

van Geel, B. 1978. A palaeoecological study of Holocene peat bog sections in Germany and the Netherlands, based on the analysis of pollen, spores, and macro- and microscopic remains of fungi, algae, cormophytes, and animals. Review of Palaeobotany and Palynology 25:1-120.

von Post, L. 1925. Einige Aufgaben der regionalen Moorforschung. Sveriges Geologiska Undersökning Series C. Number 337.

von Post, L., and R. Sernander. 1910. Pflanzenphysiognomische Studien auf Torfmooren in Närke. Livretguide des excursions en Suède du XI Congres de Geologie. University of Stockholm, Stockholm, Sweden.

Walker, D. 1961. Peat stratigraphy and bog regeneration. Proceedings of the Linnaean Society of London 172:29-33.

Wright, H. E. 1967. A square-rod piston sampler for lake sediments. Journal of Sedimentary Petrology 37:975-976. 